\title{
History and current taxonomic status of genus Agrobacterium
}

\author{
José David Flores-Félix ${ }^{\mathrm{a}}$, Esther Menéndez ${ }^{\mathrm{a}, 1}$, Alvaro Peix $^{\mathrm{b}, \mathrm{c}}$, Paula García-Fraile ${ }^{\mathrm{a}}$, \\ Encarna Velázquez ${ }^{\mathrm{a}, \mathrm{c}, *}$ \\ a Departamento de Microbiología y Genética and Instituto Hispanoluso de Investigaciones Agrarias (CIALE), Universidad de Salamanca, Salamanca, Spain \\ b Instituto de Recursos Naturales y Agrobiología, IRNASA-CSIC, Salamanca, Spain \\ c Unidad Asociada Grupo de Interacción Planta-Microorganismo (Universidad de Salamanca-IRNASA-CSIC), Salamanca, Spain
}

\section{A R T I C L E I N F O}

\section{Article history:}

Received 21 May 2019

Received in revised form

15 November 2019

Accepted 22 November 2019

\section{Keywords:}

Agrobacterium

Taxonomy

Rhizobium

Allorhizobium

\begin{abstract}
A B S T R A C T
The genus Agrobacterium was created a century ago by Conn who included it in the family Rhizobiaceae together with the genus Rhizobium. Initially, the genus Agrobacterium contained the non-pathogenic species Agrobacterium radiobacter and the plant pathogenic species Agrobacterium tumefaciens and Agrobacterium rhizogenes. At the end of the past century two new pathogenic species, Agrobacterium rubi and Agrobacterium vitis, were added to the genus. Already in the present century these species plus Agrobacterium larrymoorei were reclassified into genus Rhizobium. This reclassification was controversial and for a time both genus names were used when new species were described. Few years ago, after a taxonomic revision based on genomic data, the old species A. rhizogenes was maintained in the genus Rhizobium, the old species A. vitis was transferred to the genus Allorhizobium and several Rhizobium species were transferred to the genus Agrobacterium, which currently contains 14 species including the old species A. radiobacter, A. tumefaciens, A. rubi and A. larrymoorei. Most of these species are able to produce tumours in different plants, nevertheless the genus Agrobacterium also encompasses nonpathogenic species, one species able to nodulate legumes and one human pathogenic species. Taking into account that the species affiliations to five Agrobacterium genomospecies have not been determined yet, an increase in the number of species within this genus is expected in the near future.
\end{abstract}

(C) 2019 Published by Elsevier GmbH.

\section{The Agrobacterium taxonomy in the past century}

The genus Agrobacterium was created by Conn [9] who included it within the family Rhizobiaceae [8] together with the genus Rhizobium [14]. In the 5th edition of the Bergey's Manual of Determinative Bacteriology, the species included into the genus Agrobacterium were Agrobacterium radiobacter, Agrobacterium tumefaciens and Agrobacterium rhizogenes. In the 6th edition of this Manual the plant tumorigenic species Agrobacterium rubi $[17,48]$ was included, being differentiated from $A$. tumefaciens on the basis of the ability to reduce nitrate to nitrite [6]. In the 7th edition of this Manual the species Agrobacterium stellulatum, Agrobacterium pseudotsugae and Agrobacterium gypsophilae were added to the genus [7], but this inclusion was later considered

\footnotetext{
* Corresponding author at: Departamento de Microbiología y Genética, Lab. 209, Edificio Departamental de Biología. Campus Miguel de Unamuno, 37007 Salamanca, Spain.

E-mail address: evp@usal.es (E. Velázquez).

1 Current affiliation: ICAAM - Instituto de Ciências Agrárias e Ambientais Mediterrânicas, Laboratório de Microbiologia do Solo, Universidade de Évora.
}

unjustified because they probably belong to other genera [23]. Therefore, in the subsequent 8th edition of the Bergey's Manual only four species were included, $A$. radiobacter, which was non-pathogenic, $A$. rhizogenes, which induced hairy roots, and $A$. tumefaciens and $A$. rubi, which induced plant galls. The differentiation of these species was based on some phenotypic characteristics together with their ability to produce diverse symptoms in different plants [1]. These four species were included in the validation lists of Skerman et al. [45], who indicated that $A$. tumefaciens is the type species of genus Agrobacterium.

During the 70 and 80 s of the past century, several studies including strains isolated from different sources were performed and the existence of different varieties, biovars and/or biotypes was deeply revised by Young [58]. Some authors proposed that the species $A$. tumefaciens and $A$. radiobacter constitute a single species, $A$. radiobacter [20], later named $A$. radiobacter var. tumefaciens [21]. However, considering that $A$. tumefaciens was considered the type species of the genus Agrobacterium by Skerman et al. [45], Holmes and Roberts considered that the correct name for the unified taxon is A. tumefaciens [18]. 
Nonetheless, in the 1st edition of the Bergey's Manual of Systematic Bacteriology publishsed in 1984, Kersters and de Ley [22] maintained the four species, but they included three biovars in the species $A$. tumefaciens and two biovars in the species $A$. radiobacter, assigning the species $A$. rhizogenes to a namely biovar 2 and maintaining the species $A$. rubi. In this edition of the Bergeyś Manual a higher number of phenotypic characteristics were recorded for the Agrobacterium species, but their differentiation continued to be mainly based on phenotypic and phytopatogenicity tests [22].

At the beginning of the 90 s several changes were proposed within the genus Agrobacterium including the description of new species, nevertheless none of these changes were recorded in the 9 th and last edition of the Bergey's Manual of Determinative Bacteriology published in 1994, which included the same species that the previous version of this Manual [19]. In year 1990 the strains from the biovar 3 of $A$. tumefaciens producing tumours in Vitis vinifera were included into a new species of genus Agrobacterium named A. vitis [32]. In the description of this species, in addition to the classic phenotypic and phytopatogenicy tests, the authors carried out DNA-DNA hybridization among the type strains of the Agrobacterium species described to date and among several strains of the new proposed ones. The results obtained in this work showed that the type strain of $A$. vitis presented less than $50 \%$ DNA-DNA relatedness with respect to the type strains of the remaining Agrobacterium species, whereas the analysed strains of $A$. vitis presented values ranging from 80 to $92 \%$ among them. Surprisingly, the type strains A. tumefaciens NCPPB $2437^{\mathrm{T}}$ and A. radiobacter ATCC $19358^{\mathrm{T}}$ also presented DNA-DNA relatedness values within this range [32].

In 1992, Rüger and Höfle [41] included several strains isolated from marine sources in several species of the genus Agrobacterium recovering the names A. stellulatum, Agrobacterium ferrugineum and Agrobacterium gelatinovorum, which were not included in the validation lists of Skerman et al. [45], and proposing the new species Agrobacterium atlanticum and Agrobacterium meteori. In this work the Agrobacterium species previously described were not included and the classification of the new proposed ones was based in the initial assignement of $A$. stellulatum to the genus Agrobacterium [47] being differentiated the new species on the basis of phenotypic traits and the low DNA-DNA relatedness found among them [41]. All these species were later reclassified in other genera. The species Agrobacterium atlanticum and Agrobacterium meteori were reclassified into Ruegeria atlantica [51,52]. The type strain of Agrobacterium ferrugineum was reclassified into Pseudorhodobacter ferrugineus $[50,53]$ and the strain LMG 128 into Hoeflea marina [37]. Agrobacterium stellulatum was reclassified into Stappia stellulata [51,52] and Agrobacterium gelatinovorum was reclassified into Ruegeria gelatinovorans [51,52] and later into Thalassobius gelatinovorus [2].

A year after, Sawada et al. [43] revised the taxonomic status of Agrobacterium species described until year 1990. In this work the 16S rRNA ( $r r s$ ) gene sequences of representative strains of the biovar 1 (A. tumefaciens-A. radiobacter), biovar 2 (A. rhizogenes), biovar 3 (A. vitis) and A. rubi were obtained and compared with those of the several species from different alpha Proteobacteria genera, including the genus Rhizobium. The analysis of this gene showed that the strains from biovar 1 were related to $A$. rubi, but those from the biovars 2 and 3 were phylogenetically divergent being the strains from the biovar 2 very closely related to the type strain of Rhizobium tropici. Nevertheless, despite the species $A$. rhizogenes was emended, it was maintained within the genus Agrobacterium. Moreover, it was reported that the type strains of $A$. tumefaciens $\mathrm{NCPPB} 2437^{\mathrm{T}}$ and $A$. radiobacter IAM $12048^{\mathrm{T}}$ have $87 \%$ DNA-DNA relatedness in agreement with the results from Ophel and Kerr [32] for $A$. tumefaciens NCPPB $2437^{\mathrm{T}}$ and A. radiobacter ATCC $19358^{\mathrm{T}}$. Therefore, Sawada et al. concluded that these two strains cannot be placed in different species and they indicated that according to the Rule 38 of the
International Code of Nomenclature of Bacteria the species established earlier should be maintained [28]. Since $A$. radiobacter was described in 1902 (as Bacillus radiobacter) by Beijerinck and van Delden [4] and A. tumefaciens was described in 1907 (as Bacterium tumefaciens) by Smith and Townsend [46], Sawada et al. [43] proposed to name the strains of biovar 1 as $A$. radiobacter and to reject the species name $A$. tumefaciens. Thus, at the end of the past century A. radiobacter, A. rhizogenes, $A$. rubi and $A$. vitis were considered the valid species of genus Agrobacterium.

\section{The taxonomy of genus Agrobacterium from 2000 onwards}

The most relevant and conflictive change in the taxonomic status of genus Agrobacterium took place in year 2001 when Young et al. [60] proposed the reclassification of the complete genus Agrobacterium into the genus Rhizobium. This reclassification was based on the results of Sawada et al. [43] and, therefore, the Agrobacterium species were reclassified as Rhizobium radiobacter, Rhizobium rhizogenes, Rhizobium rubi and Rhizobium vitis. The reclassification, which was based on the rrs gene sequences analysed by Maximum-likelihood and Neighbour-joining methods, was not accepted by many authors who signed the letter of Farrand et al. [13]. These authors considered that only the biovar 2 belongs to genus Rhizobium and that classical and molecular data support that Agrobacterium and Rhizobium are different genera. This letter was later replied by Young et al. [61] and the controversy was settled by keeping the reclassification. Considering this decission, Young [57] also proposed the reclassification of the species Agrobacterium larrymoorei, which was described in 2001 [5], as Rhizobium larrymoorei. Nevertheless, this species was not included in the 2nd edition of the Bergey's Manual which only included the species A. tumefaciens, A. rhizogenes, A. rubi and A. radiobacter. Curiously, in this edition of Bergey's Manual the official reclassification of Agrobacterium species into the genus Rhizobium was disregarded, although the authors make a historical review of the nomenclature problems affecting the genus Agrobacterium over the time [59].

Due to the confusion generated after the reclassification of genus Agrobacterium into genus Rhizobium, the new species described since 2001 outside the official journal for description of new taxa of Prokaryotes (IJSEM) were named Agrobacterium, as occurred in the case of Agrobacterium albertimagni isolated from aquatic plants, in whose description, as occurred in the case of $A$. larrymoorei described a year before, only the rrs gene was included [42]. However, the species described outside the mentioned journal were named Rhizobium and the analysis of several housekeeping genes was included in their descriptions in addition to that of the rrs gene. These species were Rhizobium pusense, isolated from chickpea rhizosphere [35], Rhizobium nepotum, isolated from tumours of different plants [38] and Rhizobium skierniewicense isolated from tumours of chrysanthemum and cherry plum [39].

In parallel, the Agrobacterium strains from different species were distributed into the genomic groups (genomic species, genomospecies, genomovars) G1 to G9, G11, two unnamed genomic groups and $\mathrm{G} 13[10,11,30]$. At the time of these works, the $\mathrm{G} 4$ included the type strains of $A$. tumefaciens and $A$. radiobacter, the G11 that of $A$. rubi, the G10 that of $A$. rhizogenes and the two unnamed groups included several strains of $A$. larrymoorei and $A$. vitis [30]. Later it was shown that the G8 corresponds to the species A. fabrum [29], the $\mathrm{G} 2$ to the species $R$. pusense [3,35] and a new genomovar, named G14, corresponds to the species $R$. nepotum [38,44].

The taxonomic status of these species was changed again when Mousavi et al. [31] based on the analysis of the $\operatorname{rrs}$, recA, atpD and $r p o B$ genes proposed to transfer $R$. pusense, $R$. nepotum and $R$. skierniewicense to genus Agrobacterium and $R$. vitis (initially $A$. vitis) to genus Allorhizobium, as new combinations, which were 
Table 1

Species currently included in the genus Agrobacterium and species causing tumours or hairy roots currently included in other genera of Family Rhizobiaceae.

\begin{tabular}{|c|c|c|c|}
\hline Species & Source of isolation & Pathogenicity symptoms & References \\
\hline \multicolumn{4}{|c|}{ Genus Agrobacterium } \\
\hline A. radiobacter & Soil and plant rhizosphere & Non-pathogenic & {$[4,9]$} \\
\hline A. tumefaciens ${ }^{\text {a }}$ & Malus sp. tumours & Tumours & {$[9,46]$} \\
\hline A. rubi & Rubus sp. tumours & Tumours & {$[17,48]$} \\
\hline A. larrymoorei & Ficus benjamina tumours & Tumours & {$[5]$} \\
\hline 'A. albertimagni' & Potamogeton pectinatus & No data & {$[42]$} \\
\hline 'A. fabrum' & Prunus sp., Humulus lupulus, Euonymus alata, Rubus macropetalus tumours & Tumours & [29] \\
\hline A. pusense & Cicer arietinum rhizosphere & No data & {$[31,35]$} \\
\hline A. nepotum & Prunus, Vitis and Rubus tumours & Tumours & {$[31,38]$} \\
\hline A. skierniewicense & Chrysanthemum and Prunus tumours & Tumours & [39] \\
\hline A. arsenijevicii & Prunus and Rubus tumours & Tumours & {$[25]$} \\
\hline 'A. deltaense' & Sesbania cannabina nodules & No data & {$[55]$} \\
\hline A. salinitolerans & Sesbania cannabina nodules & No data & {$[56]$} \\
\hline 'A. bohemicum' & Papaver somniferum & Non-pathogenic & [62] \\
\hline A. rosae & Rosa $\times$ hybrida tumours & Tumours & {$[26]$} \\
\hline \multicolumn{4}{|c|}{ Genus Allorhizobium } \\
\hline A. vitis & Vitis vinifera tumours & Tumours & {$[31,32]$} \\
\hline \multicolumn{4}{|l|}{ Genus Rhizobium } \\
\hline$R$. rhizogenes & Malus sp. & Hairy roots & {$[9,40]$} \\
\hline 'R. tumorigenes' & Rubus sp. tumours & Tumours & [27] \\
\hline
\end{tabular}

a We have included these two species names taking into account the current decision of the Judicial Commision [49]. Gan et al. [22] proposed that they belong to different subspecies of the species $A$. radiobacter. The quoted names correspond to species that have not been officially validated to date.

later validated in IJSEM [33]. The old species A. rhizogenes was maintained as Rhizobium rhizogenes in the genus Rhizobium, which currently also contains the new species Rhizobium tumorigenes able to induce plant tumours [27]. Mousavi et al. [31] did not considered the species Agrobacterium fabrum isolated from tumours of various plants [29] because it was not officially proposed, although the complete genome of its type strain C58 was the first obtained for a member of the genus Agrobacterium and it was sequenced twice independently due to the importance of this strain for plant genetic engineering $[16,54]$.

Since 2015, several new species of genus Agrobacterium have been described based on the analyses of the rrs and several housekeeping genes and, in some cases, the complete genomes. Some of these species were isolated from plant tumours, such as Agrobacterium arsenijevicii [25] and Agrobacterium rosae [26], but others were isolated from legume nodules, such as Agrobacterium deltaense [55] and Agrobacterium salinitolerans [56], or plant wastes, such as Agrobacterium bohemicum [62]. In some of these works a strain named KB-105 (ATCC31113) from Agrobacterium viscosum was mentioned [12], nevertheless this species has not been officially proposed and moreover the strain KB-105, which is not a type strain, is currently included in a patent (U.S. Patent Number $4,028,185$ ). Therefore, $A$. viscosum cannot be considered a valid species to date and then it has not been included in the present study.

Concerning to the old species of genus Agrobacterium that were not transferred to other genera by Mousavi et al. [31], they return to their initial names $A$. tumefaciens, $A$. radiobacter, $A$. rubi and $A$. larrymoorei. Nevertheless, there is a problem with the names of the two first species as was pointed out by Sawada et al. [43] who, considering that the name $A$. radiobacter has priority, proposed the rejection of the name $A$. tumefaciens. Nevertheless, according to Rule 56a of the International Code of Nomenclature of Bacteria, only the Judicial Commission can place a name on the list of rejected names [28,36]. After years of discussion about this issue, the last decision of this Commission taken in 2014 is that "the combination Agrobacterium radiobacter (Beijerinck and van Delden 1902) Conn 1942 has priority over the combination Agrobacterium tumefaciens (Smith and Townsend 1907) Conn 1942 when the two are treated as members of the same species based on the principle of priority as applied to the corresponding specific epithets. The type species of the genus is Agrobacterium tumefaciens (Smith and Townsend 1907) Conn 1942, even if treated as a later heterotypic synonym of Agrobacterium radiobacter (Beijerinck and van Delden 1902) Conn 1942. Agrobacterium tumefaciens (Smith and Townsend 1907) Conn 1942 is typified by the strain defined on the Approved Lists of Bacterial Names and by strains known to be derived from the nomenclatural type" [49].

In 2014, the same year the decision of the Judicial Commission was published, Zhang et al. [63] sequenced the genome of the type strain of $A$. radiobacter held in DSMZ culture collection $\left(\mathrm{DSM} 30147^{\mathrm{T}}\right.$ ) and proposed the emendation of this species in order to include the results of assimilation of different carbon sources, the production of several enzymes and the fatty acid profile. These authors indicated that the genome of the strain DSM $30147^{\mathrm{T}}$ was unusually large, since it has more than $7 \mathrm{Mb}$ whereas the remaining analysed genomes have sizes ranging from 4.8 to $6.8 \mathrm{Mb}$. Nevertheless, in the present year 2019, Gan et al. [15] reported the reason of this difference, which was a contamination of the genome of the strain DSM $30147^{\mathrm{T}}$ (GCF_000421945) with part of the genome of the strain TS43 also isolated by Zhang et al. [63] (GCF_001526605). The genomic data were not included in the protologue of the emended species $A$. radiobacter, but in any case the emendation is not valid to date since it was not officially performed.

In the work of Gan et al. [15] the genomes of the type strains of $A$. tumefaciens B6 ${ }^{\mathrm{T}}$ (LMVK01000030.1, FCNL01000034.1) and A. radiobacter NCPPB $3001^{\mathrm{T}}$ (LMVJ01000011.1) were obtained and compared with the availabe genome of the strain A. radiobacter LMG $140^{\mathrm{T}}$ (MRDG01000013.1) concluding that the type strains of A. tumefaciens and A. radiobacter represent two subspecies from the same species. These authors, taking into account that the combination Agrobacterium radiobacter has priority over the combination Agrobacterium tumefaciens [49], proposed that A. tumefaciens B6 $^{\mathrm{T}}$ should be reclassified into a new subspecies of $A$. radiobacter. However, this proposal can not be accepted because the protologues of the two proposed subspecies were not included in the paper of Gan et al. [15] and moreover it is necessary a new emendation of the species $A$. radiobacter. In any case, this proposal does not modify the resolution of the Judicial Commission given that the specific name Agrobacterium tumefaciens can not be rejected as long as this Commission has not made such decision.

Therefore, the genus Agrobacterium currently contains 14 species if we consider the names $A$. radiobacter and $A$. tumefaciens and the species $A$. fabrum, although this species has not been still proposed (Table 1). One of them, A. albertimagni, is more closely related to some Rhizobium species forming a rrs gene cluster 


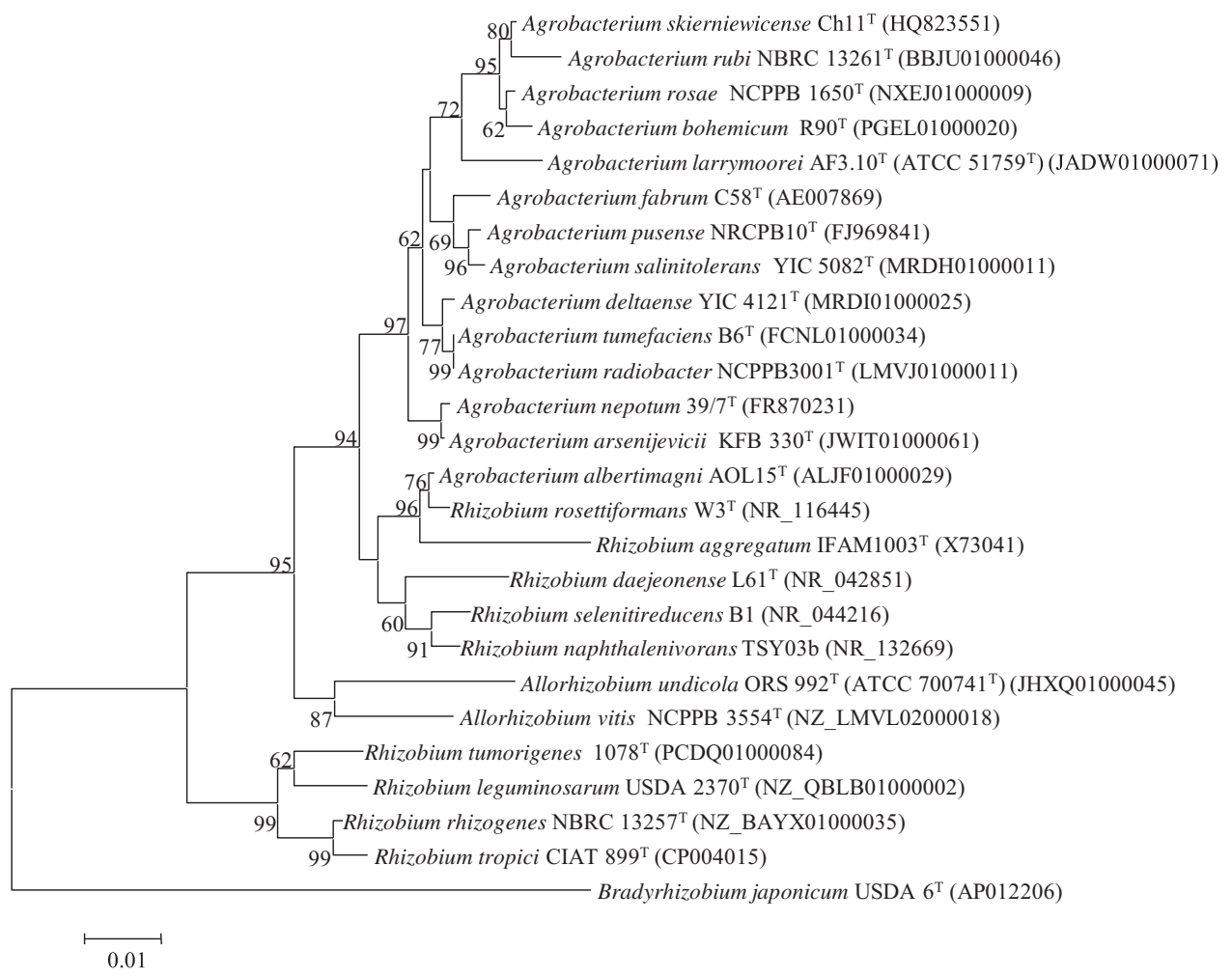

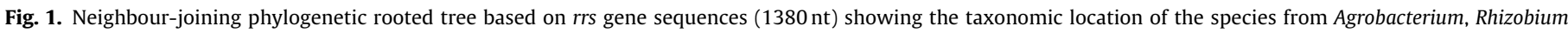

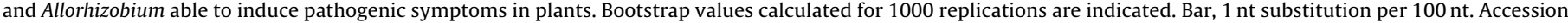
numbers from Genbank are given in brackets.

(Fig. 1) that belong to neither Agrobacterium nor Rhizobium but to a separate genus [12,34]. Nevertheless, the reclassification of $A$. albertimagni in a new genus will need further studies since currently the genomes of several Rhizobium species belonging to this putative new genus are not available. The remaining species currently included within genus Agrobacterium formed a rrs cluster phylogenetically divergent to genera Allorhizobium and Rhizobium also containing plant pathogenic species (Fig. 1). Most of Agrobacterium species are able to produce tumours in different plants (Table 1 ), nevertheless the number of non-pathogenic species had incresed in the last two years, with one of them, A. salinitolerans, able to nodulate the legume Sesbania cannabina [56] and other, A. pusense, frequently isolated from clinical sources [3], able to cause human sepsis [24]. If we take into account that the strains belonging to five defined genomospecies have not been assigned to an Agrobacterium species yet, a significant increase in its number is expected in a near future.

\section{Aknowledgements}

This work was supported by MINECO (Spanish Central Government) Grant AGL2013-48098-P to EV. EM was granted by a postdoctoral contract associated to this project.

\section{References}

[1] Allen, O.N., Holding, A.J. (1974) Genus II. Agrobacterium Conn 1942, 359. In: Buchanan, R.E., Gibbons, N.E. (Eds.), Bergey's Manual of Determinative Bacteriology, 8th ed., Williams \& Wilkins, Baltimore, pp. 264-267.

[2] Arahal, D.R., Macián, M.C., Garay, E., Pujalte, M.J. (2005) Thalassobius mediterraneus gen. nov., sp. nov., and reclassification of Ruegeria gelatinovorans as Thalassobius gelatinovorus comb. nov. Int. J. Syst. Evol. Microbiol. 55, 2371-2376.

[3] Aujoulat, F., Marchandin, H., Zorgniotti, I., Masnou, A., Jumas-Bilak, E. (2015) Rhizobium pusense is the main human pathogen in the genus Agrobacterium/Rhizobium. Clin. Microbiol. Infect. 21 (472), e1-e5.
[4] Beijerinck, M.W., van Delden, A. 1902 Über die Assimilation des freien Stickstoffs durch Bakerien Zentralblatt für Bakteriologie, Parasitenkunde, Infektionskrankheiten und Hygiene, 9, Abteilung II, pp. , 3-43.

[5] Bouzar, H., Jones, J.B. (2001) Agrobacterium larrymoorei sp. nov., a pathogen isolated from aerial tumours of Ficus benjamina. Int. J. Syst. Evol. Microbiol. 51, 1023-1026

[6] Breed, R.S., Murray, E.G.D., Hitchens, A.P. 1948 Bergey’s Manual of Determinative Bacteriology, 6th ed., The Williams \& Wilkins Co., Baltimore, pp. , 227-231.

[7] Breed, R.S., Murray, E.G.D., Smith, N.R. 1957 Bergey's Manual of Determinative Bacteriology, 7th ed., The Williams \& Wilkins Co., Baltimore, pp. , 288-294.

[8] Conn, H.J. (1938) Taxonomic relationships of certain non-sporeforming rods in soil. J. Bacteriol. 36, 320-321.

[9] Conn, H.J. (1942) Validity of the genus Alcaligenes. J. Bacteriol. 44, 353-360.

[10] Costechareyre, D., Bertolla, F., Nesme, X. (2009) Homologous recombination in Agrobacterium: potential implications for the genomic species concept in bacteria. Mol. Biol. Evol. 26, 167-176.

[11] Costechareyre, D., Rhouma, A., Lavire, C., Portier, P., Chapulliot, D., Bertolla, F. Boubaker, A., Dessaux, Y., Nesme, X. (2010) Rapid and efficient identification of Agrobacterium species by recA allele analysis: Agrobacterium recA diversity. Microb. Ecol. 60, 862-872.

[12] de Lajudie, P., Young, J.P.W. (2018) International Committee on Systematics of Prokaryotes Subcommittee on the taxonomy of rhizobia and agrobacteria. Minutes of the closed meeting, Granada, 4 September 2017. Int. J. Syst. Evol. Microbiol. 68, 3363-3368.

[13] Farrand, S.K., van Berkum, P.B., Oger, P. (2003) Agrobacterium is a definable genus of the family Rhizobiaceae. Int. J. Syst. Evol. Microbiol. 53, 1681-1687.

[14] Frank, B. (1889) Ueber die Pilzsymbiose der Leguminosen. Bet. Dtsch. Bot. Ges. 7, 332-346.

[15] Gan, H.M., Lee, M.V.L., Savka, M.A. (2019) Improved genome of Agrobacterium radiobacter type strain provides new taxonomic insight into Agrobacterium genomospecies 4. PeerJ 7, e6366.

[16] Goodner, B., Hinkle, G., Gattung, S., Miller, N., Blanchard, M., Qurollo, B., Goldman, B.S., Cao, Y., Askenazi, M., Halling, C., Mullin, L., Houmiel, K., Gordon, J., Vaudin, M., Iartchouk, O., Epp, A., Liu, F., Wollam, C., Allinger, M., Doughty, D., Scott, C., Lappas, C., Markelz, B., Flanagan, C., Crowell, C., Gurson, J., Lomo, C., Sear, C., Strub, G., Cielo, C., Slater, S. (2001) Genome sequence of the plant pathogen and biotechnology agent Agrobacterium tumefaciens C58. Science 294, 2323-2328.

[17] Hildebrand, E.M. (1940) Cane gall of brambles caused by Phytomonas n. sp. J. Agric. Res. 61, 685-696.

[18] Holmes, B., Roberts, P. (1981) The classification, identification and nomenclature of Agrobacteria. J. Appl. Bacteriol. 50, 443-467.

[19] Holt, J.G. 1994 Bergey's Manual of Determinative Bacteriology, 9th ed., Williams \& Wilkins, Baltimore, pp. , 244-254, pp. 130. 
[20] Keane, P.., Kerr, A., New, P.B. (1970) Crown gall of stone fruit II. Identification and nomenclature of Agrobacterium isolates. Aust. J. Biol. Sci. 23, 585-596.

[21] Kerr, A., Panagopoulos, C.G. (1977) Biotypes of Agrobacterium radiobacter var. tumefaciens and their biological control. J. Phytopathol. 90, 172-179.

[22] Kersters, K., De Ley, J. (1984) Genus III. Agrobacterium Conn 1942, in: Krieg, N.R., Holt, J.G. (Eds.), Bergey's Manual of Systematic Bacteriology, vol. 1, 1st ed. Williams \& Wilkins, Baltimore, pp. 244-254.

[23] Kersters, K., De Ley, J., Sneath, P.H.A., Sackin, M. (1973) Numerical taxonomic analysis of Agrobacterium. J. Gen. Microbiol. 78, 227-239.

[24] Kuchibiro, T., Hirayama, K., Houdai, K., Nakamura, T., Ohnuma, K., Tomida, J. Kawamura, Y. (2018) First case report of sepsis caused by Rhizobium pusense in Japan. JMM Case Rep 5, e005135.

[25] Kuzmanović, N., Puławska, J., Prokić, A., Ivanović, M., Zlatković, N., Jones, J.B., Obradović, A. (2015) Agrobacterium arsenijevicii sp. nov., isolated from crown gall tumors on raspberry and cherry plum. Syst. Appl. Microbiol. 38, 373-378.

[26] Kuzmanović, N., Puławska, J., Smalla, K., Nesme, X. (2018) Agrobacterium rosae sp. nov., isolated from galls on different agricultural crops. Syst. Appl. Microbiol. 41, 191-197.

[27] Kuzmanović, N., Smalla, K., Gronow, S., Puławska, J. (2018) Rhizobium tumorigenes sp. nov., a novel plant tumorigenic bacterium isolated from cane gall tumors on thornless blackberry. Sci. Rep. 8, 9051.

[28] Lapage, S.P., Sneath, P.H.A., Lessel, E.F., Skerman, V.B.D., Seeliger, H.P.R., Clark, W.A. 1992 International code of nomenclature of bacteria, 1990 revision, American Society for Microbiology, Washington, D.C.

[29] Lassalle, F., Campillo, T., Vial, L., Baude, J., Costechareyre, D., Chapulliot, D., Shams, M., Abrouk, D., Lavire, C., Oger-Desfeux, C., Hommais, F., Guéguen, L., Daubin, V., Muller, D., Nesme, X. (2011) Genomic species are ecological species as revealed by comparative genomics in Agrobacterium tumefaciens. Genome Biol. Evol. 3, 762-781.

[30] Mougel, C., Thioulouse, J., Perrière, G., Nesme, X. (2002)A mathematical method for determining genome divergence and species delineation using AFLP. Int. J. Syst. Evol. Microbiol. 52, 573-586.

[31] Mousavi, S.A., Willems, A., Nesme, X., de Lajudie, P., Lindström, K. (2015) Revised phylogeny of Rhizobiaceae: proposal of the delineation of Pararhizobium gen. nov., and 13 new species combinations. Syst. Appl. Microbiol. 38, 84-90.

[32] Ophel, K., Kerr, A. (1990) Agrobacterium vitis sp. nov. for strains of Agrobacterium biovar 3 from grapevines. Int. J. Syst. Bacteriol. 40, 236-241.

[33] Oren, A., Garrity, G.M. (2016) Validation List no. 172. List of new names and new combinations previously effectively, but not validly, published. Int. J. Syst. Evol. Microbiol. 66, 4299-4305.

[34] Ormeño-Orrillo, E., Servín-Garcidueñas, L.E., Rogel, M.A., González, V., Peralta, H., Mora, J., Martínez-Romero, J., Martínez-Romero, E. (2015) Taxonomy of rhizobia and agrobacteria from the Rhizobiaceae family in light of genomics. Syst. Appl. Microbiol. 38, 287-291.

[35] Panday, D., Schumann, P. Das, S.K. (2011) Rhizobium pusense sp. nov., isolated from the rhizosphere of chickpea (Cicer arietinum L.). Int. J. Syst. Evol. Microbiol. $61,2632-2639$.

[36] Parker, C.T., Tindall, B.J., Garrity, G.M. (2019) International code of nomenclature of Prokaryotes. Int. J. Syst. Evol. Microbiol. 69, S1-S111.

[37] Peix, A., Rivas, R., Trujillo, M.E., Vancanneyt, M., Velázquez, E., Willems, A. (2005) Reclassification of Agrobacterium ferrugineum LMG 128 as Hoeflea marina gen. nov., sp. nov. Int. J. Syst. Evol. Microbiol. 55, 1163-1166.

[38] Puławska, J., Willems, A., de Meyer, S.E., Süle, S. (2012) Rhizobium nepotum sp. nov. isolated from tumors on different plant species. Syst. Appl. Microbiol. 35, 215-220.

[39] Puławska, J., Willems, A., Sobiczewski, P. (2012) Rhizobium skierniewicense sp. nov., isolated from tumours on chrysanthemum and cherry plum. Int. J. Syst. Evol. Microbiol. 62, 895-899.

[40] Riker, A.J., Banfield, W.M., Wright, W.H., Keitt, G.W., Sagen, H.E. (1930) Studies on infectious hairy-root of nursery apple trees. J. Agric. Res. 41, 507-540.

[41] Rüger, H.J., Höfle, M. (1992) Marine star-shaped-aggregate-forming bacteria: Agrobacterium atlanticum sp. nov.; Agrobacterium meteori sp. nov.; Agrobacterium ferrugineum sp. nov., nom. rev.; Agrobacterium gelatinovorum sp. nov., nom. rev.; and Agrobacterium stellulatum sp. nov., nom. rev. Int. J. Syst. Bacteriol. 42, $133-143$.

[42] Salmassi, T.M., Venkateswaren, K., Satomi, M., Newman, D.K., Hering. J.G. (2002) Oxidation of arsenite by Agrobacterium albertimagni, AOL15, sp. nov., isolated from Hot Creek, California. Geomicrobiology 19, 53-66

[43] Sawada, H., Ieki, H., Oyaizu, H., Matsumoto, S. (1993) Proposal for rejection of Agrobacterium tumefaciens and revised descriptions for the genus Agrobacterium and for Agrobacterium radiobacter and Agrobacterium rhizogenes. Int. J. Syst. Bacteriol. 43, 694-702.

[44] Shams, M., Vial, L., Chapulliot, D., Nesme, X., Lavire, C. (2013) Rapid and accurate species and genomic species identification and exhaustive population diversity assessment of Agrobacterium spp. using recA-based PCR. Syst. Appl. Microbiol. 36, 351-358

[45] Skerman, V.B.D., Mcgowan, V., Sneath, P.H.A. (1980) Approved lists of bacterial names. Int. J. Syst. Bacteriol. 30, 225-420.

[46] Smith, E.F., Townsend, C.O. (1907) A plant-tumor of bacterial origin. Science 25, 671-673.

[47] Stapp, C., Knosel, D. (1954) Zur Genetik sternbildender Bakterien. Zentralbl. Bakteriol. Parasitenkd. Infektionskr. Hyg. Abt. 108, 243-259.

[48] Starr, M.P., Weiss, J.E. (1943) Growth of phytopathogenic bacteria in a synthetic asparagin medium. Phytopathology 33, 314-318.

[49] Tindall, B.J. (2014) Agrobacterium radiobacter (Beijerinck and van Delden 1902) Conn 1942 has priority over Agrobacterium tumefaciens (Smith and Townsend 1907) Conn 1942 when the two are treated as members of the same species based on the principle of priority and Rule 23a, Note 1 as applied to the corresponding specific epithets. Opinion 94. Judicial Commission of the International Committee on Systematics of Prokaryotes. Int. J. Syst. Evol. Microbiol. 64, 3590-3592.

[50] Uchino, Y., Hamada, T., Yokota, A. (2002) Proposal of Pseudorhodobacter ferrugineus gen nov, comb nov, for a non-photosynthetic marine bacterium, Agrobacterium ferrugineum, related to the genus Rhodobacter. J. Gen. Appl. Microbiol. 48, 309-319.

[51] Uchino, Y., Hirata, A., Yokota, A., Sugiyama, J. (1998) Reclassification of marine Agrobacterium species: proposals of Stappia stellulata gen. nov., comb. nov. Stappia aggregata sp. nov., nom. rev., Ruegeria atlantica gen. nov., comb. nov., Ruegeria gelatinovora comb. nov., Ruegeria algicola comb. nov., and Ahrensia kieliense gen. nov., sp. nov., nom. rev. J. Gen. Appl. Microbiol. 44, 201-210.

[52] Validation List no. 68, (1999) Validation of publication of new names and new combinations previously effectively published outside the IJSB. Int. J. Syst. Evol. Microbiol. 49, 1-3.

[53] Validation List no. 92, (2003) Validation of publication of new names and new combinations previously effectively published outside the IJSB. Int. J. Syst. Evol. Microbiol. 53, 935-937.

[54] Wood, D.W., Setubal, J.C., Kaul, R., Monks, D.E., Kitajima, J.P., Okura, V.K., Zhou, Y., Chen, L., Wood, G.E., Almeida, N.F., Jr., Woo, L., Chen, Y., Paulsen, I.T., Eisen, J.A., Karp, P.D., Bovee, D., Sr., Chapman, P., Clendenning, J., Deatherage, G., Gillet, W., Grant, C., Kutyavin, T., Levy, R., Li, M.J., McClelland, E., Palmieri, A., Raymond, C., Rouse, G., Saenphimmachak, C., Wu, Z., Romero, P., Gordon, D., Zhang, S., Yoo, H., Tao, Y., Biddle, P., Jung, M., Krespan, W., Perry, M., Gordon-Kamm, B., Liao, L. Kim, S., Hendrick, C., Zhao, Z.Y., Dolan, M., Chumley, F., Tingey, S.V., Tomb, J.F., Gordon, M.P., Olson, M.V., Nester, E.W. (2001) The genome of the natural genetic engineer Agrobacterium tumefaciens C58. Science 294, 2317-2323.

[55] Yan, J., Li, Y., Han, X.Z., Chen, W.F., Zou, W.X., Xie, Z., Li, M. (2017) Agrobacterium deltaense sp. nov., an endophytic bacteria isolated from nodule of Sesbania cannabina. Arch. Microbiol. 199, 1003-1009.

[56] Yan, J., Li, Y., Yan, H., Chen, W.F., Zhang, X., Wang, E.T., Han, X.Z., Xie, Z.H. (2017) Agrobacterium salinitolerans Sp. nov, a saline-alkaline-tolerant bacterium isolated from root nodule of Sesbania cannabina. Int. J. Syst. Evol. Microbiol. 67, 1906-1911.

[57] Young. J.M. (2004) Renaming of Agrobacterium larrymoorei Bouzar and Jones 2001 as Rhizobium larrymoorei (Bouzar and Jones 2001) comb. nov. Int. J. Syst. Evol. Microbiol. 54, 149.

[58] Young, J.M. (2008) Agrobacterium-taxonomy of plant-pathogenic Rhizobium species. In: Tzfira, T., Citovsky, V. (Eds.), Agrobacterium: From Biology to Biotechnology, Springer, New York, NY, pp. 183-220.

[59] Young, J.M., Kerr, A., Sawada, H. (2005) Agrobacterium, in: Brenner, D.J., Krieg, N.R., Staley, J.T., Garrity, G.M. (Eds.), The Alpha-, Beta-, Delta- and Epsilonproteobacteria, The Proteobacteria, Part C, Bergey's Manual of Systematic Bacteriology, vol. 2, 2nd. Ed., Springer, New York, pp. 340-345.

[60] Young, J.M., Kuykendall, L.D., Martínez-Romero, E., Kerr, A., Sawada, H. (2001) A revision of Rhizobium Frank 1889, with an emended description of the genus, and the inclusion of all species of Agrobacterium Conn 1942 and Allorhizobium undicola de Lajudie et al. 1998 as new combinations: Rhizobium radiobacter, $R$. rhizogenes, R. rubi, R. undicola and R. vitis. Int. J. Syst. Evol. Microbiol. 51, 89-103.

[61] Young, J.M., Kuykendall, L.D., Martínez-Romero, E., Kerr, A., Sawada, H. (2003) Classification and nomenclature of Agrobacterium and Rhizobium - a reply to Farrand et al. (2003). Int. J. Syst. Evol. Microbiol. 53, 1689-1695.

[62] Zahradník, J., Nunvar, J., Pařízková, H., Kolářová, L., Palyzová, A., Marešová, H. Grulich, M., Kyslíková, E., Kyslík, P. (2018) Agrobacterium bohemicum sp. nov. isolated from poppy seed wastes in central Bohemia. Syst. Appl. Microbiol. 41, 184-190.

[63] Zhang, L., Li, X., Zhang, F., Wang, G. (2014) Genomic analysis of Agrobacterium radiobacter DSM $30147^{\mathrm{T}}$ and emended description of $A$. radiobacter (Beijerinck and van Delden 1902) Conn 1942 (Approved Lists 1980) emend. Sawada et al. 1993. Stand. Genomic Sci. 9, 3. 